\title{
SIKAP MANJA PADA ANAK DAN UPAYA MENGATASINYA
}

\author{
Oleh : Suriati \\ $* * *$
}

\begin{abstract}
Abstrak
Anak adalah anugrah Allah yang besar dan harus dipertanggungjawabkan oleh para orang tua, sehingga menjadi hal yang kodrati, manakala orang tua sangat menyayangi anak-anaknya. Semua dengan dalih agar anak-anak mereka dapat tumbuh secara optimal dan sesuai dengan harapan orang tua. Untuk mewujudkan hal tersebut, tampak adanya perbedaan antara orang tua yang satu dengan orang tua yang lainnya.

Orang tua sering memberikan kebebasan kepada anak-anaknya dengan harapan mereka dapat menjadi orang mandiri. Tetapi di sisi lain, terdapat pula orang tua yang sangat protectif terhadap anak-anaknya. Sikap inilah yang selalu membawa anak-anak tumbuh menjadi anak-anak manja. Konsekuwnsi logisnya, anak akan susah bersosialisasi, beradaptasi, dan kelak susah untuk hidup mandiri. Agama Islam menegaskan agar setiap orang tua tidak meninggalkan anak-anak mereka dalam keadaan lemah. Lemah dalam konteks ini memiliki beberapa pemaknaan. Beberapa di antaranya susah bersosialisasi, beradaptasi, dan kelak susah untuk hidup mandiri. Oleh karena itu, orang tua yang bijaksana adalah orang tua yang tidak memberikan kebebasan kepada anak-anaknya dan tidak pula menampakkan sikap over-protectif kepada anak-anaknya.
\end{abstract}

Kata Kunci : Sikap manja pada anak, upaya mengatasinya

\section{PENDAHULUAN}

$\mathrm{D}$ i tengah-tengah perkembangan dunia yang ditandai dengan pesatnya ilmu pengetahuan dan teknologi diiringi dengan perubahan sosial yang sangat cepat, sering dijumpai orang tua yang terlalu sibuk dengan pekerjaan di luar rumah dan menyerahkan tanggung jawab sepenuhnya kepada pembantu untuk menjaga dan merawat anak-anaknya dengan fasilitas yang serba ada tanpa memperdulikan pengaruh pada anak tersebut. Namun di sisi lain, terdapat juga orang tua yang terlalu memanjakan anak-anaknya, baik memanjakan berupa materi maupun memanjakan dengan kasih sayang yang sangat berlebihan. Mereka tidak menyadari bahwa perlakukan memanjakan anak sesungguhnya memberikan pengaruh buruk kepada anak tersebut. Pengaruh buruk yang dimaksud adalah menjadikan anak pasif dan kurang bertanggungjawab. Kedua prototipe orang tua tersebut semuanya untuk kebaikan anak-anaknya kelak. 


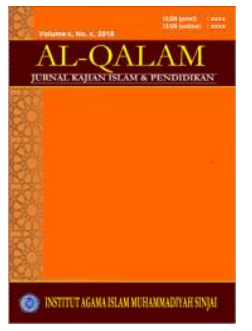

AL-QALAM

Jurmal Kajian Islam \& Pendidikan

Volume 06 No 012014

ISSN (print) : 1858-4152

ISSN (online) : -

Homepage : http://journal.iaimsinjai.ac.id/index.php/al-qalam

Hal ini dapat dimaklumi karena setiap orang tua tentu menginginkan anaknya menjadi orang yang berkembang secara sempurna. Bagi sebuah keluarga, anak merupakan salah satu rahmat dan karunia Allah yang patut disyukuri. Selain itu, anak juga amanat dari Allah kepada kedua orang tua yang wajib dipertanggungjawabkan. Jelas, tanggung jawab orang tua terhadap anak tidak kecil. Secara umum inti tanggung jawab itu ialah penyelenggaraan pendidikan bagi anak-anak dalam rumah tangga. ${ }^{1}$

Perlakukan orang tua yang terlalu berlebihan memberikan kasih sayangnya, membuat anak itu tumbuh menjadi manja. Hal ini dapat memberikan pengaruh terhadap perkembangan jiwa anak, sehingga menjadi lemah dan tidak bisa mandiri karena selalu tergantung kepada orang tuanya. Jika hal seperti ini terjadi, maka resiko yang ditimbulkannya juga akan kembali kepada orang tuanya. Penyebabnya, anak yang manja sering merepotkan orang tua, baik sewaktu masih kecil maupun terlebih jika memasuki usia dewasa. Akibat lain adalah anak akan sulit untuk dididik dan memahami perilakunya sendiri.

Oleh karena itu, orang tua hendaknya menyadari bahwa setiap anak itu memiliki potensi dasar yang harus dikembangkan dengan cara sendiri-sendiri. Di sinilah peran orang tua memberikan arahan-arahan dan motivasi agar arah perkembangan tersebut tidak menyimpang dari harapan yang diinginkan. Betapa tidak, warna yang muncul dari setiap anak sangat dipengaruhi oleh pola pembinaan yang diberikan oleh orang tuanya. Rasulullah menegaskan dalam haditsnya yang diriwayatkan oleh Imam Muslim dari Abi Hurairah ra. yang berarti "tidaklah anak itu dilahirkan melainkan dalam keadaan fitrah (kecenderungan untuk percaya kepada Allah Swt.), maka kedua orang tuanyalah yang menjadikan anak beragama Yahudi, Nasrani, dan Majusi."2

Berdasarkan Hadits tersebut dapat dipahami bahwa sejak lahir dan tumbuh menjadi dewasa tidak terlepas dari pengaruh manusia di sekitarnya, terutama hubungan yang pertama dan utama, yakni orang tua. Oleh karena itu, situasi dari pendidikan keluarga yang baik, sopan santun, berpendidikan, bermoral yang tinggi mencerminkan manusia yang baik dan bertanggungjawab atas dirinya sendiri maupun terhadap bangsa dan agamanya harus ditumbuh-kembangkan.

Mendidik anak melalui cara yang keras dan kaku dampaknya akan sama dengan menyikapi anak secara masa bodoh dan meremehkan. Di sisi lain, sikap memanjakan yang kelewat batas juga akan memberikan hasil yang tidak memuaskan. ${ }^{3}$ Orang tua memiliki kewajiban untuk menolong anak-anak dalam memenuhi kebutuhan mereka, akan tetapi mereka tidak boleh berlebih-lebihan

\footnotetext{
${ }^{1}$ Ahmad Tafsir, Ilmu Pendidikan dalam Perspektif Islam, (Cet. II ; Bandung: Remaja Rosdakarya, 1994), h. 160

${ }^{2}$ Al-Imam Abi Abdillah Muhammad Bin Ismail Al-Bukhari, Shahih Bukhari, Jilid I, Juz II (Beirut : Darul Fikhi, 1981) h. 260

${ }^{3}$ A. Choiran Marzuki, Anak Saleh dalam Asuhan Ibu Muslimah, (et. III ; Yogyakarta: Mitra Pustaka, 2000), h. 127
} 


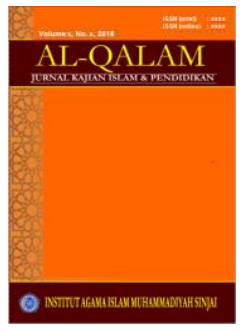

AL-QALAM

Jurmal Kajian Islam \& Pendidikan

Volume 06 No 012014

ISSN (print) : 1858-4152

ISSN (online) : -

Homepage : http://journal.iaimsinjai.ac.id/index.php/al-qalam

dalam menolong itu. Sehingga anak-anak mereka tidak kehilangan kemampuan untuk berdiri sendiri. ${ }^{4}$

Anak yang manja jika dewasa cenderung tidak memiliki kemandirian, karena mereka selalu melibatkan campur tangan orang tua dalam menyelesaikan persoalan, baik sederhana maupun rumit. Mereka tidak dapat berdiri sendiri dan selalu menggantungkan diri pada orang lain. Oleh karena pentingnya penanaman sikap mandiri pada anak, maka orang tua harus memulainya sejak dini. Meskipun tidak berarti bahwa orang tua melepas begitu saja dan membiarkannya tumbuh dengan sendirinya.

Pendidikan yang didasarkan pada kasih sayang yang terlampau berlebihan akan memberikan dampak negatif terhadap anak itu sendiri, yang justru akan menghambat kepribadiannya. Pendidikan seperti ini merupakan pendidikan yang salah dalam sebuah keluarga. Bila demikian, maka pendidikan yang benar dalam persoalan kasih sayang terhadap anak adalah dengan menjaga keseimbangan "khairul umur ausatuha" dan menjauhi ifrath dan tafrith (melebihkan dan mengurangi). ${ }^{5}$

Tidak dapat dipungkiri bila orang tua selalu berusaha menghindari tindakan yang membuat anak mereka sedih. Apalagi bagi orang tua yang memiliki hanya satu anak. Mereka akan berusaha apa saja yang dapat membahagiakan anak dengan cara memenuhi semua kebutuhannya. Orang tua dari golongan yang memiliki kekayaan mempunyai kecenderungan untuk memanjakan anak-anaknya dengan mewujudkan semua permintaan anakanaknya. ${ }^{6}$

Menyikapi hal tersebut, maka sebgai orang tua hendaknya senantiasa memperhatikan pola pembinaan anak. Hal ini disebabkan agar orang tua dapat mewjudkan anak-anak islami dan mandiri ${ }^{7}$ dalam mengarungi kehidupannya kelak.

\section{PEMBAHASAN}

\section{A. Faktor Terjadinya Sikap Manja Pada Anak}

\footnotetext{
${ }^{4}$ Abdul Aziz El-Quussy, Pokok-pokok Kesehatan Jiwa/Mental, Jilid I, Alih Bahasa Zakiah Daradjat (Jakarta: Bulan Bintang, 1983), h. 220.

${ }^{5}$ Husain Mazhahiri, Pintar Mendidik Anak, (Jakarta: Lentera, 1999), h. 150.

${ }^{6}$ Slameto, Belajar dan Faktor-Faktor yang Mempengaruhinya, (Cet. III ; Jakarta: Rineka Cipta, 1995), h. 64

${ }^{7}$ KataMandiri mempunyai arti "keadaan dapat berdiri sendiri, tanpa tergantung pada orang lain" (lihat Tim Penyusun Kamus Pusat Bahasa, Kamus Besar Bahasa Indonesia, Edisi ketiga Cet. III ; Jakarta: Balai Pustaka, 2005, h. 710). Sedangkan menurut Zakiah Daradjat "mandiri" adalah kecenderugan anak untuk melakukan suatu yang diingininya tanpa minta bantuan orang lain" (lihat Zakiah Daradjat, Perawatan Jiwa untuk Anak-anak, Jakarta: Bulan Bintang, 1987, h. 130).
} 


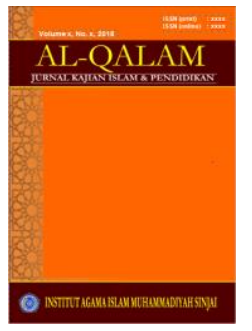

AL-QALAM

Jurmal Kajian Islam \& Pendidikan

Volume 06 No 012014

ISSN (print) : 1858-4152

ISSN (online) : -

Homepage : http://journal.iaimsinjai.ac.id/index.php/al-qalam

Anak adalah anugrah Allah swt. yang harus dipertanggungjawabkan di hari kemudian. Untuk itu, anak harus diberikan pendidikan yang terbaik agar mereka dapat hidup sesuai dengan tuntunan dan tuntutan agama. Hanya saja dalam perkembangannya, terkadang sebagian orang tua melupakan bahwa anak yang dididik tidak hanya dengan memberikan materi belaka. Sebab hal ini akan menjadikan anak-anak justru jauh dari apa yang diharapkan. Anak-anak akan tumbuh sebagai anak yang manja dan pada akhirnya susah diatur.

Hal-hal lain yang menjadikan seorang anak tumbuh dan berkembang menjadi anak yang bersikap manja adalah :

1. Orang terlalu menuruti kemauan anaknya di luar batas kewajaran.

Di dalam masyarakat yang bersaing, banyak orang tua yang ingin menjadi ayah atau ibu yang super. Mereka mendambakan anaknya menikmati suasana kehidupan dengan jalan memberikan segala sesuatu apapun yang diminta anaknya tanpa melihat terlebih dahulu tujuan dari keinginan anak tersebut. Anak-anak akan mengembangkan pemikiran bahwa mereka akan diperhatikan dan diturti jika hanya mereka yang menduduki pusat perhatian keluarga. ${ }^{8}$

Hal semacam ini dapat terjadi pada lingkungan keluarga yang kurang mengerti pada lingkungan anak-anak. Mereka mengira bahwa dengan memberikan dan menuruti semua keinginan anaknya itu adalah kewajibannya sudah dijalankan, meka sudah menyadari bahwa hal ini kurang baik bagi pertumbuhan dan perkembangan jiwa anak. Atau hal ini dapat juga terjadi pada orang tua yang telah mengerti dan tahu cara mendidik anak, tetapi kerena beliau tidak tega menolak setiap permintaan anaknya. Ia merasa takut kalau anaknya akan melakukan sesuatu yang tidak dikehendakinya.

Tetapi ada juga orang tua yang tidak mau susah karena ulah anaknya yang ingin mudahnya saja atau enaknya saja. Dia takut kalau-kalau si anak bertingkah atau membandel dan terus merengek-rengek jika kehendaknya tidak dituruti. Lagi pula dengan begitu dia merasa lebih mudah berbuat menuruti kehendak anaknya daripada berlaku sabar diri sambil mencari akal yang lebih bijaksana dan bersifat paedagogis. Hal ini pula yang menyebabkan adanya pengasuh yang seringkali memanjakan anak majikannya. Ia takut akan kesukaran yang timbul dari si anak dan kemarahan majikannya. Dengan demikian, dalam memilih pembantu untuk mengurusi si anak hendaknya berhati-hati. ${ }^{9}$

Tindakan orang tua seperti dijelaskan sebelumnya adalah merupakan tindakan yang salah dan kurang bijaksana, sebab yang demikian itu dapat membuat si anak akan lebih menyukarkan dan akan menuntut lebih banyak lagi daripadanya, dan hal ini juga sangat tidak sesuai dengan tuntunan agama Islam.

${ }^{8}$ Maurice Balson, Bagaimana Menjadi Orang Tua Yang Baik (Cet. I ; Jakarta : Bumi Aksara, 1993) h. 37

${ }^{9}$ M. Ngalim Purwanto, Ilmu Pendidikan Teoritis dan Praktis (Cet. III ; Bandung : Remaja Karya, 1987) h. 110 


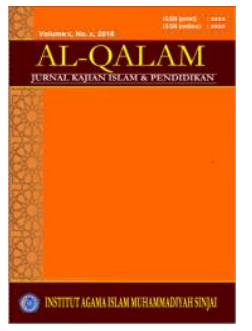

AL-QALAM

Jurmal Kajian Islam \& Pendidikan

Volume 06 No 012014

ISSN (print) : 1858-4152

ISSN (online) : -

Homepage : http://journal.iaimsinjai.ac.id/index.php/al-qalam

Dalam hal ini orang tua perlu mengendalikan diri dan menyadari bahwa tidak semua permintaan dan keinginan anak itu harus dipenuhi. Walaupun dalam Islam itu senantiasa menghendaki penganutnya untuk memenuhi segala kebutuahan anak dan meladeninya jika diperlukan. Hanya saja dalam peladenan itu ditekankan agar tidak terlalu berlebihan sebab segala sesuatunya memiliki batas-batas tersendiri. Setiap anak butuh bimbingan dan kasih sayang serta perhatian dari orang lain terutama dari kedua orang tuanya sepanjang perhatian tersebut tidak melewati batas kewajaran.

2. Memberikan kebebasan penuh kepada anak sesuai kehendaknya.

Kebebasan merupakan hak yang pokok bagi manusia sebagaimana yang termuat dalam hak asasi manusia. ${ }^{10}$ Hak-hak asasi manusia yang dimaksudkan adalah kasih sayang, rasa aman, harga diri, dan kebebasan lainnya harus diperhatikan betul-betul.

Setiap orang itu diberikan kebebasan karena jika tidak, maka akan timbullah tantangan terhadap orang yang memperkosa kebebasan itu. Kebebasan yang dimaksudkan oleh penulis bukanlah kebebasan yang tidak mengenal batas, tetapi kebebasan yang berada dalam batas-batas kewajaran.

Mengenai kebutuhan anak akan kebebasan, yaitu kebebasan terbatas, dimaksudkan agar anak tidak tumbuh samrawut, sehingga ahli pendidikan dan psikologi mengatakan bahwah anak adalah makhluk yang khusus. Anak berada dalam perjuangannya untuk terjun ke dalam dunia manusia yang dewasa lagi sempurna. Manusia adalah makhluk yang tumbuh secara terus menerus yang dalam pertumbuhannya tidak akan sempurna, kecuali harus melalui gerak dan kegiatan. ${ }^{11}$

Gerak dan kegiatan timbul dari diri makhluk itu sendiri. Oleh karena itu, tidak akan ada pertumbuhan tanpa ada kebebasan, karena kebebasan itu termasuk kebutuhan pokok. Dengan adanya kebebasan dan kegitan pada anak, maka kegairahan dan gerak yang menyertainya akan menjadi pengalaman yang dibutuhkan bagi pertumbuhan badan, akal, akhlak, sosial, keahlian, dan pengetahuan.

Suatu kekeliruan yang besar pada pendidikan, manakala orang tua menganggap pemberian kebebasan pada anak akan berdampak positif. Apalagi, jika anak menyalahgunakan kebebasan yang diberikan oleh orang tuanya. Tentu anak akan menjadi orang yang "liar" lebih-lebih jika dalan kehidupan anak cenderung pada hal-hal yang terlarang.

${ }^{10}$ Muh. Ali Quthb, Auladuna Fi Dlau-it Tarbiyatil Islamiyah, diterjemahkan oleh Bahrum Abu Bakar Ihsan dengan judul Sang ANak DAlam Naungan Pendidikan Islam (Cet. II ; Bandung : Diponegoro, 1993) h. 69

${ }^{11}$ Zakiah Daradjat, Agama Sebagai Kebutuhan Hidup, Nasenat Perkawinan dan Keluarga, No. 223, Januari 19991 h. 36 


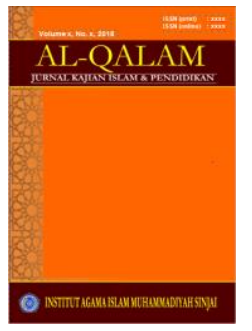

AL-QALAM

Jurmal Kajian Islam \& Pendidikan

Volume 06 No 012014

ISSN (print) : 1858-4152

ISSN (online) : -

Homepage : http://journal.iaimsinjai.ac.id/index.php/al-qalam

Dengan demikian, orang tua hendaklah memberikan kebebasan kepada anaknya dengan kebebasan yang sewajarnya, misalnya dalam urusan-urusan pribadinya seperti dalam hal permainan dan mengeluarkan pendapatnya. Menentukan bagaimana seharusnya anak itu bermain, karena permainan pada umur anak-anak hanyalah bertujuan untuk menambah dan memperkuat ototototnya motoriknya. Untuk itu mungkin akan mendorong-dorong kursi, naik turun tangga, dan lain-lain. ${ }^{12}$

Orang tua yang tidak mengerti bahwa permainan seperti itu untuk memperkuat otot-ototnya sering membatasi aktivitas anaknya. Jika hal ini terjadi, maka pertumbuhan dan perkembangan si anak akan terhalang. Meskipun demikian, orang tua tetap harus waspada dan mempelajari permainan anakanaknya yang dapat merugikan perkembangan jiwa anak-anaknya. Jadi, fungsi memberikan kebebasan bermain pada anak-anak adalah memperlancar pertumbuhan fisiknya, menguatkan otot-otot serta menumbuhkan kecakapan dan mengembangkan bakat yang ada padanya.

Selain memberikan kebebasan bermain pada anak, kebebasan berkawan dengan anak-anak lain pun harus diberikan pada si anak. Hal ini disebabkan agar jiwa sosial anak dapat tumbuh secara optimal. Sikap sosial ini akan tercermin pada cara mengahadapi teman, cara menekan keinginan supaya sesuai dengan teman-teman tersebut.

Harus dipahami, meskipun memberikan kebebasan perlu dilakukan oleh orang tua, tetapi hendaknya jangan berlebihan, karena dapat berakibat fatal pada pertumbuhan dan perkembangan jiwa anak. Bahkan berpotensi menumbuhkan sikap manja dalam lingkungan keluarganya.

3. Adanya orang tua yang memberikan kasih sayang secara berlebihan

Kasih sayang bagian dari perlindungan dan perlindungan bagian dari kasih sayang ${ }^{13}$ dan kasih sayang itu muncul karena adanya perhatian terhadap orang yang kita cintai, terutama dalam hal ini adalah kasih sayang orang tua terhadap anaknya. Sikap dan kasih sayang orang tua merupakan dasar dari segala perlakuan dalam menghadapi anak. Hal inisebabkan orang tua adalah poros bagi anaknya dan interaksi antara kebutuhan kasih sayang dan tuntutan lainnya.

Di dalam hati sanubari anak yang masih kecil terdapat kebutuhan yang paling mendasar, yaitu curahan cinta dan kasih sayang ibu-bapak dan saudarasaudarnya. Cinta dan kasih sayang akan menyiapkan dasar bagi pembentukan konsep moral yang sehat. ${ }^{14}$ Bagi setiap anak, jika seorang anak dibesarkan dalam lingkungan yang dilingkupi oleh cinta dan kasih sayang, kelak setelah dewasa

${ }^{12}$ Zakiah Daradjat, Ibid., h. 44

${ }^{13}$ Dewan Ulama AL-Azhar, Child Care In Islam, diterjemahkan oleh AlwiyahAbdurahman dengan judul, Ajaran Islam Tentang Perawatan Anak (Cet. VIII;Mesir: ALBayan, 1992) h. 37

${ }^{14}$ Yedi Kuiawan, Pendidikan Anak Sejk ini Hingga masa Depan, (Cet. I; Jakart: Firdaus, 1992) h. 66 


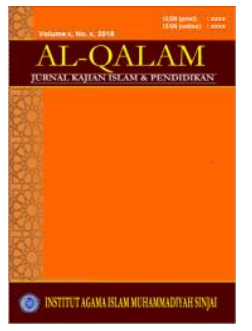

AL-QALAM

Jurmal Kajian Islam \& Pendidikan

Volume 06 No 012014

ISSN (print) : 1858-4152

ISSN (online) : -

Homepage : http://journal.iaimsinjai.ac.id/index.php/al-qalam

akan mampu menghadap berbagai permasalahan dalam kehidupan tanpa diliputi rasa kegelisahan atau kecemasan. Akan tetapi, memberikan cinta dan kasih sayang secara berlebih-lebihan terhadap anak juga tidak dibenarkan. ${ }^{15}$ Sebab hal ini dapat membuat anak menjadi manja dan acapkali akan membawa anak pada sifat-sifat pasrah, mudah menyerah dan putus asa dalam mengatasi prolem kehidupan, sehingga cederung menyandarkan nasibnya pada orang lain.

Oleh karena itu, orang tua tidak boleh melupakan anak karena kesibukan, tetapi pada sisi yang lain, orang tua juga tidak boleh terjebak pada pemberian kasih sayang yang berlebihan. Beberapa penyebab orang tua meberikan kasih sayang yang berlebihan pada anak-anaknya :

a. Hubungan antara ibu dan bapak yang kurang hangat atau tidak ada kasih sayang satu sama lain, menyebabkan orang tua terutama ibu mencari kepuasan dengan berlebih-lebihan menyayagi anaknya.

b. Karena bapak meninggal atau terlalu banyak tugas di luar, sehingga ibu menumpahkan perhatian dan kasih sayang yang berlebihan kepada anaknya.

c. Orang tua sewaku kecilnya kehilangan kasih sayang dari orang tuanya, lalu ia berusaha menghindarkan anaknya dari perasaan yang ia pernah alami dahulu. ${ }^{16}$

d. Ibu yang terlalu banyak memiliki sifat keibuan.

e. Ibu yang mempunyai perasaan bersalah yang ingin ditutupi dengan cara menunjukkan kasih sayang yang berlebih-lebihan. ${ }^{17}$

Sebenarnya perhatian dan kasih sayang itu bukan hal yang salah, bahkan perhatian itu merupakan ungkapan rasa kasih dan sayang, Cuma ungkapan kasih sayang itu sering menjurus pada sikap memanjakan bila diberikan secara berlebihan.

Oleh kerena itu, orang tua haruslah berhati-hati dalam memberikan kasih sayang kepada anak, jangan sampai kasih sayang yang kita berikan itu menjurus pada pemanjaan, sebab hal ini dapat mempengaruhi pertumbuhan dan perkembangan jiwa anak.

4. Pemberian Bantuan Secara Terus-menerus

Peran orang tua sebagai penolong dan pembantu adalah memberikan bantuan kepada anak, karena ia masih memiliki keterbatasan dan kelemahan baik fisik, psikis, maupun ruhaniahnya. Bantuan dimaksud adalah membawa anak kepada keadaan yang wajar dan mandiri. Bantuan itu berupa tindakan-tindakan yang mempercepat kedewasaan, dalam bentuk perawatan fisik, penggunaan anggota badan dan pemeliharaan ruhani.

Selama kemampuan anak untuk berdiri sendiri belum ada, anak tentu membutuhkan pertolongan orang dewasa. Orang tua memiliki kewajiban untuk menolong anak-anaknya dalam memenuhi kebutuhan mereka, tetapi mereka tidak

\footnotetext{
${ }^{15}$ Ibid, h. 67

${ }^{16}$ Zakiah Daradjat, Kesehatan Mental, (Cet. XVI ; Jakarta : Haji Masangung, 1990), h. 67

${ }^{17}$ Singgih D. Gunarsa dan Ny. Singgih D. Gunarsa, Psikologi Untuk Membimbing (Ce.t. V ; Jakarta : Gunung Mulia, 1987), h. 84
} 


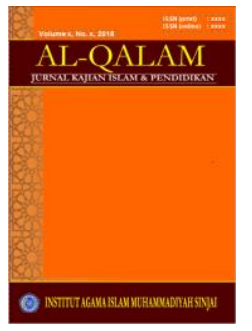

AL-QALAM

Jurmal Kajian Islam \& Pendidikan

Volume 06 No 012014

ISSN (print) : 1858-4152

ISSN (online) : -

Homepage : http://journal.iaimsinjai.ac.id/index.php/al-qalam

boleh berlebih-lebihan dalam menolong anak, sehingga nantinya anak mereka tidak akan kehilangan kemampuan untuk berdiri sendiri. ${ }^{18}$

Semua anak yang terlahir ke dunia ini merupakan makhluk yang independen dan kompleks. Makhluk independen yang dimaksud dalam hal ini adalah ciptaan Allah yang berdiri sendiri, memiliki takdir tersendiri dan merupakan individu yang terlepas dari individu lain termasuk orang tuanya sekalipun. Selanjutnya, anak disebut makhluk yang kompleks karena seorang anak lahir dengan membawa karakter, bakat serta kemampuan tertentu untuk dapat dikembangkan. ${ }^{19}$

Memecahkan Masalah Anak

Orang tua sering tidak memberi kepercayaan pada anak atas kemampuan yang dimilikinya. Mereka sering turun tangan untuk membantu memecahkan masalah mereka, padahal belum tentu bantuan tersebut benar-benar dibutuhkan oleh seorang anak. Pada dasarnya Allah Swt telah memberi karunia yang berupa intuisi pada setiap anak agar mereka dapat memecahkan berbagai masalah, dan dengan memecahkan masalah tersebut mereka dapat mengasah intuisinya secara lebih tajam. ${ }^{20}$

Orang tua tidak sadar bahwa kemampuan memecahkan masalah adalah bagian yang menyatu dalam proses pertumbuhan anak. Ada pula orang tua yang suka mencampuri urusan anak-anaknya sampai kepada soal-soal yang kecil, misalnya mereka mengatur jadwal kegiatan anak-anaknya, cara membelanjakan uang, teman-teman bermain dan lain-lain. Anak-anak yang dibesarkan dalam suasana seperti itu, jika mereka dewasa akan memiliki sifat ragu-ragu, lemah kepribadian dan tidak sanggup mengambil keputusan tentang apa saja. Hal ini dikarenakan mereka belum pernah terlatih untuk mengambil keputusan bagi dirinya sendiri, karena selama ini ada orang yang selalu memikirkannya. Dalam hal ini mungkin orang tua lupa bahwa seseorang akan belajar dari pengalamannya.

Orang tua harus mengajarkan anak-anaknya untuk mempelajari segala sesuatu sendirian, artinya mereka akan merasakan hasil perbuatan mereka sendiri baik yang menyenangkan atau yang menyakitkan. Berawal dari pengalaman tersebut, anak akan belajar untuk mengmbil keputusan, memecahkan masalah, serta memunculkan ide-ide kreatif yang dimilikinya. Mereka akan mendapatkan pelajaran tersendiri melalui pengalaman pribadinya secara langsung. Seperti yang dikemukakan Stephanie Thornton dalam bukunya Children Solving Problem, bahwa "pemecahan masalah yang berhasil tidak begitu bergantung kepada kecerdasan si anak tetapi lebih pada pengalaman mereka". ${ }^{21}$

\footnotetext{
${ }^{18}$ Abdul Aziz El-Quussy, op. cit., h. 220.

${ }^{19}$ M. Nipan Abdul Halim, Anak Saleh Dambaan Keluarga, (Yogyakarta: Pustaka Pelajar, 2001), h.19

${ }^{20}$ Irawati Istadi, Mendidik dengan Cinta, (Bekasi: Pustaka Inti, 2006), h. 47.

${ }^{21}$ Lawrence E. Shapiro, Mengajarkan Emotional Intelligence Pada Anak, Alih Bahasa Alex Tri Kantjono, (Cet. IV ; Jakarta : Gramedia Pustaka Utama, 2001), h. 141
} 


\section{B. Upaya Yang Ditempuh Untuk Mengatasi Sikap Manja Anak}

Ngalim Purwanto, mengemukakan upaya yang dapat dilakukan untuk mengatasi sikap manja pada seorang anak dengan melakukan beberapa hal, yakni

1. Janganlah mengindahkan anak yang manja itu lebih daripada anak-anak yang lainnya. Setiap pendidik diharapkan berusaha agar anak yang manja itu dapat menginsafi dirinya bahwa ia tidak berbeda dengan anak-anak yang lain. Mereka semua sama dan tidak ada yang istimewa.

2. Setiap pendidik hendaklah menanamkan rasa percaya pada kemampuan diri sendiri kepada anak manja. Dalam hal ini, usaha yang dapat dilakukan oleh pendidik hendaknya tidak memberikan pertolongan kepada anak tersebut jika tidak perlu betul ; biarkan ia menyelesaikan sendiri masalahnya.

3. Besarkan hatinya terhadap hasil-hasil usaha yang telah dikerjakannya sendiri dan sekali-sekali pujilah jika itu memang perlu untuk membesarkan hatinya agar tidak bertambah kecil hatinya serta merasa bahwa apa yang dikerjakannya tidak sia-sia.

4. Kembangkan rasa sosial pada anak tersebut dan biasakan ia bekerja sama dengan teman-temannya, bantu membantu antara satu dengan yang lainnya.

5. Setiap pendidik diharapkan dapat menginsyafi perbuatannya bahwa memanjakan anak itu adalah sesuatu perbuatan yang tidak baik dan merupakan suatu kekeliruan yang sangat besar. ${ }^{22}$

Berdasarkan hal tersebut, dapat diketahui dan lebih mudah menentukan metode yang cocok bagi anak manja sekaligus dapat menjauhkan pandangan yang keliru yang akan timbul dalam keluarga.

Selain itu, Singgih D. Gunarsa dan Ny. Singgih D. Gunarsa mengemukakan langkah-langkah untuk menangani anak yang menjadi masalah karena terlalu manja. Beberapa hal yang dapat dilakukan adalah:

a. Orang tua harus merencanakan pendidikan yang pasti dan tegas dan konsisten dalam menjalankan renacana tersebut.

b. Orang tua memuji dan memenuhi keinginan dan kelakukan yang baik dan lebih dewasa.

c. Orang tua harus menyadarkan akan keuntungan-keuntungan sikap dan tingkah laku yang masuk akal dengan acara menolak dan tidak mengabulkan permintaan anak yang luar biasa, kekanak-kanakan atau yang bertentangan dengan perencanaan orang tua.

d. Pada anak yang lebih besar perlu diterangkan bahwa perubahan sikap orang tua dengan segala ketegasan adalah untuk kebaikan anak itu sendiri.

${ }^{22}$ M. Ngalim Purwanto, op. cit., h. 12 


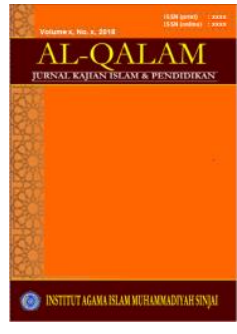

AL-QALAM

Jurnal Kajian Islam \& Pendidikan

Volume 06 No 012014

ISSN (print) : 1858-4152

ISSN (online) :-

Homepage : http://journal.iaimsinjai.ac.id/index.php/al-qalam

e. Anak harus diyakinkan bahwa ia tetap memperoleh kasih sayang dan akan memetik manfaat dari cara orang tua yang tegas ini. ${ }^{23}$

Namun demikian, semua hal tersebut hanya dapat berhasil jika terjalin kerja sama di antara anggota keluarga, sebab dengan adanya kerjasama perkembangan perilaku anak manja dapat dikontrol. Kerjasama ini diharapkan akan meberikan manfaat bagi pertumbuhan dan perkembangan jiwa anak. Anak akan diwarnai dan diisi dengan pendidikan yang bermanfaat dengan mengacu kepada materi dan metode yang sesuai dengan ajaran-ajaran Islam.

\section{KESIMPULAN}

1. Sikap dan perlakukan orang tua dalam mendidik anaknya sangat berpengaruh terhadap perkembangan jiwa anak.

2. Upaya yang dapat dilakukan untuk mengatasi terjadinya sikap manja pada anak adalah para orang tua harus menginsafi bahwa sikap memanjakan anak itu kurang baik bagi pertumbuhan dan perkembangan jiwa anak, dan harus memberikan pendidikan yang lebih positif kepada anak agar percaya pada kemampuan sendiri dan dapat mandiri serta memiliki tanggung jawab.

${ }^{23}$ Singgih D. Gunarsa dan Ny. SInggih D. Gunarsa, op. cit., h. 86 


\section{DAFTAR PUSTAKA}

Balson, Maurice. Bagaimana Menjadi Orang Tua Yang Baik, Cet. I ; Jakarta : Bumi Aksara, 1993

Al-Bukhari, Al-Imam Abi Abdillah Muhammad Bin Ismail. Shahih Bukhari, Jilid I, Juz II, Beirut : Darul Fikhi, 1981

Choiran, Marzuki, A. Anak Saleh dalam Asuhan Ibu Muslimah, Cet. III ; Yogyakarta: Mitra Pustaka, 2000

Daradjat, Zakiah Perawatan Jiwa untuk Anak-anak, Jakarta: Bulan Bintang, 1987

-----------. Kesehatan Mental, Cet. XVI ; Jakarta : Haji Masangung, 1990 - Agama Sebagai Kebutuhan Hidup, Nasenat Perkawinan dan Keluarga, No. 223, Januari 1991

Dewan Ulama AL-Azhar, Child Care In Islam, diterjemahkan oleh AlwiyahAbdurahman dengan judul, Ajaran Islam Tentang Perawatan Anak, Cet. VIII;Mesir: AL- Bayan, 1992

El-Quussy, Abdul Aziz Pokok-pokok Kesehatan Jiwa/Mental, Jilid I, Alih Bahasa Zakiah Daradjat, Jakarta: Bulan Bintang, 1983

Gunarsa, Singgih D. dan Ny. Singgih D. Gunarsa, Psikologi Untuk Membimbing, Ce.t. V ; Jakarta : Gunung Mulia, 1987

Halim, M. Nipan Abdul Anak Saleh Dambaan Keluarga, Yogyakarta: Pustaka Pelajar, 2001

Istadi, Irawati Mendidik dengan Cinta, Bekasi: Pustaka Inti, 2006

Kurniawan, Yedi. Pendidikan Anak Sejak Dini Hingga masa Depan, Cet. I; Jakarta: Firdaus, 1992

Mazhahiri, Husain Pintar Mendidik Anak, Jakarta: Lentera, 1999

Purwanto, M. Ngalim. Ilmu Pendidikan Teoritis dan Praktis, Cet. III ; Bandung : Remaja Karya, 1987

Quthb, Muh. Ali. Auladuna Fi Dlau-it Tarbiyatil Islamiyah, diterjemahkan oleh Bahrum Abu Bakar Ihsan dengan judul Sang ANak DAlam Naungan Pendidikan Islam, Cet. II ; Bandung : Diponegoro, 1993

Shapiro, Lawrence E. Mengajarkan Emotional Intelligence Pada Anak, Alih Bahasa Alex Tri Kantjono, Cet. IV ; Jakarta : Gramedia Pustaka Utama, 2001

Slameto, Belajar dan Faktor-Faktor yang Mempengaruhinya, Cet. III ; Jakarta: Rineka Cipta, 1995

Tim Penyusun Kamus Pusat Bahasa, Kamus Besar Bahasa Indonesia, Edisi ketiga Cet. III ; Jakarta: Balai Pustaka, 2005 